\title{
In the Eye of the Beholder: Using Eye Tracking to Understand the Causal Influence of Governance Institutions on Attention*
}

\author{
Julie Hassing Nielsen and Dan Mønster ${ }^{\mathbf{g}}$
}

\begin{abstract}
What role does political governance institution (i.e. the local, national, and European governance level) play for political attention? Using eye tracking in a laboratory experiment $(N=63)$, we pioneer a study into exploring the role of governance institution on attention to political news, holding political content constant. We find that fixation time significantly increases when reading about the EU compared to the national and local governance institutions. The political topic (here immigration and climate) only has a significant impact as an interaction effect with the national and local levels. Sex and attitudes to EU integration play no significant role. We discuss these findings, including the prospects and limitations using eye tracking in political science research.
\end{abstract}

\section{Keywords}

Eye tracking; laboratory experiment; governance institutions; political behavior; Euroscepticism

\section{Introduction}

What role does governance institution play for attention to political news? Do individuals pay more or less attention to news that comes from a particular governance institution or governance level? The separate effect of governance institutions (here conceptualized as the three governance levels in European politics, i.e., the local, the national, and the EU level) on political news interest is rarely explored. While abundant research focuses on the role of specific policy content (e.g Hutchings and Jardina, 2009) or news framing (e.g Chong and Druckman, 2007) when looking into the role of political news or messaging on attention and opinion-formation, we know much less about the role that governance institution as "political actor" plays in itself.

Here, we answer two salient questions; to what extent does governance institutions influence political attention, and how strong is this relationship across political news content? Because the EU is a contested institution (e.g. Boomgaarden et al., 2011; Nielsen, 2018), we furthermore

\footnotetext{
*The project is funded by the Independent Research Fund Denmark

${ }^{\ddagger}$ Corresponding author: Julie Hassing Nielsen, Department of Political Science, Lund University, Email: julie.hassing_nielsen@svet.lu.se

\School of Business and Social Sciences, Aarhus University, Denmark
} 
test how attitudes towards EU integration might play a role for attention to political news. Also, because previous studies show sex differences in gazing behavior, we control for sex (Schiessl et al., 2003, p. 3-4).

To answer these questions, we use data from an eye tracking experiment $(N=63)$ conducted at Aarhus University, Cognition and Behavior Lab ${ }^{1}$. We employ a $3 \times 2$ within-subject factorial design with six political news reading treatments divided into three governance institutions (local, national, and the EU), and two political content areas (immigration and climate). The outcome variable is fixation time in treatment-related areas of interest (AOI) as a proxy for attention.

Our study has two contributions to the literature on the role of governance institutions in politics, and political news more broadly. First, we pioneer detection and separation of the individual effect of governance institutions, holding other factors like political content constant. Second, our design elaborates on eye tracking as a novel method, enabling us to assess individual components like governance institutions when exploring the broader link between political news and attention. Conventional methods in political science do not allow for such segregation, and, therefore, an individual estimation of the impact of governance institutions has been hard to obtain until now.

This research is timely. Increasing discussion about democratic fatigue in western democracies (e.g. Norris, 2011), the rise of populism (e.g. Mudde and Kaltwasser, 2012) paralleled with a deep crisis of European institutions, most predominantly resulting in Brexit (e.g. Hobolt, 2016), call for a close scrutinization of the individual factors and components that might impact individuals' political attention and, consequently, their behavior and opinion-formation. While our investigation is of general interest to the political science community, we wish to highlight its importance in an EU context, where the European institutions have suffered from a lack of media interest (e.g. De Vreese et al., 2003), and where the role of governance institution on attention and opinion-formation consequently have been extensively discussed (e.g. Nielsen and Franklin, 2017), yet remain to be empirically tested. We therefore have reasons to believe that political behavior and opinion-formation are strongly affected by governance institution, yet we have not, until now, been able to disentangle the impact of governance institution from, for example, news framing or the policy issues themselves.

While eye tracking studies are still rare in political science, they are nevertheless becoming increasingly popular. Recently, they have been used in a wide range of studies, including a study exploring attention to political cues in social media posts (Bode et al., 2017), a study on individual assessment of changes in political information (Coronel and Sweitzer, 2018), and a study exploring the effect of ballot position (Blom-Hansen et al., 2016) to mention a few examples. While these studies investigate different topics, their findings all underline that eye tracking is useful to detect the separate role of, for example, political institutions in political news consumption. The method allows us to segregate the causal effect of political content and governance institution, while holding constant other central components in news consumption, such as news framing. Furthermore, along with other experimental methods, eye tracking measures subjects' actual behavior as opposed to their self-reported behavior, where the latter is often subject to bias (e.g. Marquart et al., 2016; Schiessl et al., 2003). Finally, using eye tracking in a laboratory setting provides us with high confidence that subjects received the treatment manipulations and adhered to the experimental instructions.

We use eye tracking because, in alignment with previous research, we expect a strong eye-mind relationship, and a direct link between eye movements and higher cognitive processes (e.g. Bundesen and Habekost, 2008; Viviani, 1990) with very little lag between eye fixation and what the brain processes (Just and Carpenter, 1976). A large body of evidence supports the

\footnotetext{
${ }^{1}$ See: https://bss.au.dk/en/cognition-and-behavior-lab/
} 
eye-mind hypothesis (for more see e.g. Holmqvist et al., 2011, p. 379). Because we perceive our environment visually and gain salient information this way, it helps us to perform essential tasks (Tatler et al., 2014, p. 4), including political decision-making. Because cognitive processes, including attention, are so closely linked to gaze fixation, we follow previous research, using fixation time as a proxy for attention (e.g Marquart et al., 2016; Sülflow et al., 2019). Importantly, however, eye tracking does not provide information about the underlying processes that caused fixation (e.g. interest, frustration, complexity) (Vraga et al., 2016). Thus, our study serves as a first step in the exploration of a much broader salient question: How does the eye-mind relationship relate to actual political decision-making and behavior? We do not answer the bigger question here, but provide an answer to the first part of the equation.

Theoretically, we rely on Festinger's theory of cognitive dissonance (Festinger, 1962), emphasizing that individuals seek cognitive consistency in their lives. Cognitions are consonant if one follows logically from the other, and dissonant if the opposite is true. Cognitive dissonance is psychologically uncomfortable, and people seek to reduce dissonance, for example, by avoiding information and news that generate dissonance being inconsistent with their beliefs (Harmon-Jones and Mills, 2019, p.3-6). Elaborating on the theory of cognitive dissonance, a recent study shows that people are more prone to be influenced when making decisions by an in-group member compared to a group they do not identify strongly with (e.g. Guazzini et al., 2015). Furthermore, cognitive dissonance theory helps explain selective exposure to political advertisement that is aligned with one's previous views (Marquart et al., 2016).

Along similar lines, building on the predictions in cognitive dissonance theory, we expect that governance institutions that are less exposed in daily media, and, consequently, not strongly present in people's political mind, generate less familiarity and, thereby, enhance cognitive dissonance. Abundant research shows that the political discussions at the EU level are significantly less covered in the news and broadly debated compared to national and local governance levels (e.g. De Vreese, 2001). Because subjects are less exposed to supranational EU-related news, we expect news presented by this governance institution to be unfamiliar compared to news from the national or local governance institutions. Consequently, attention is withdrawn or avoided when exposed to EU-related news, resulting in a decrease in fixation time in our experimental treatments when exposed to EU-related news content. Hence, our first hypothesis is:

H1: Familiar governance institutions (i.e. local and national level) are associated with higher levels of attention than unfamiliar ones.

Political attitudes may play a role for attention to governance institutions. From previous studies using eye tracking, we know that fixation positively correlates with political agreement. For example, being left-wing positively affects fixation time when exposed to Green parties' advertisements (Marquart et al., 2016). Hence, in an exit questionnaire, we measure subjects' attitudes towards EU integration. We expect pro-European attitudes to correlate positively with institutional familiarity, and, hence, increase fixation time. Hence, our second hypothesis is:

H2: Support for European integration - ceteris paribus - correlates positively with attention at the EU level

Ensuring that the political content does not confound our study, our design includes two political topics (immigration and climate change). Contemporary survey data consistently ranks immigration and climate change among the top political issues of public concern. ${ }^{2}$ We apply

\footnotetext{
${ }^{2}$ See, for example, Eurobarometer 90.3. and 90.4 released in 2019.
} 
these two policy topics to ensure that variation in attention to governance institution is not confounded by policy issue. Hence, political content is included as robustness check, and we expect the relationship between governance institutions and attention remains consistent across topics. Consequently, the last hypothesis is:

H3: There is no difference in attention across political issues

\section{Experimental Procedure and Design}

To examine the link between governance institution and political attention, we conducted a laboratory experiment. The experiment was carried out in Cognition and Behavior Lab at Aarhus University in May-June $2017(N=63)$. The number of subjects is similar to previous research, where most studies include approximately 60 subjects (e.g. Bode et al., 2017; Marquart et al., 2016; Vraga et al., 2016). Subjects were university students belonging to a wide range of academic disciplines (for details see online appendix, Table A2) who were recruited through the lab participant pool. Thus, we followed the widely accepted research tradition of using student samples in laboratory experiments (Druckman and Kam, 2011; Krupnikov and Levine, 2014). The sample consisted of 34 females and 29 males (mean age $=24$ ).

Information about the experiment was sent to subjects approximately 48 hours prior participation. It was presented again upon arrival. First, subjects filled in a questionnaire. ${ }^{3}$ Second, a calibration sequence was performed, during which subjects were asked to remove any eye makeup and fixate on several points on screen, ensuring optimal data quality (Holmqvist et al., 2011, p. 128-129). Third, subjects were exposed to the experimental treatments, consisting of a within-subject $3 \times 2$ factorial design. Each subject was exposed to a total of six experimental treatments in the form of a text containing political news. After each treatment, they answered three comprehension questions about the text they had just read. Lastly, subjects were debriefed and received a fixed payment (6.6 USD). ${ }^{4}$ Payment was unrelated to experimental behavior and outcome.

Experimental research always warrants a validity discussion (e.g Morton and Williams, 2010). When well-designed, laboratory experiments, including eye tracking, are generally considered to rank high on internal validity. Yet, they are often challenged by low mundane realism (McDermott, 2011, p. 28) or external validity (McDermott, 2011; Morton and Williams, 2010). To ensure high levels of external validity and mundane validity, we pilot-tested the news policy treatments prior the experiment to ensure our treatments were realistic, did not suffer from framing or political biases, and were generally comprehensible.

Experimenter demand effects refer to behavioral changes by subjects due to cues about what constitutes appropriate behavior (e.g. Mummolo and Peterson, 2019; Zizzo, 2010). Since the experimental objective is to explore how governance institutions play a role for attention, experimenter demand effect could be introduced in the experimental tasks, for example by requiring thorough reading of political news to answer comprehension questions after the treatments. Thus, text reading was not driven only or primarily by interest, but also by the knowledge that there would be a test after each text. We return to this issue in the discussion.

The study was approved by the relevant agencies in accordance with national legislation and good practice (Gerber et al., 2014; Morton and Williams, 2010). ${ }^{5}$ Experimental details

\footnotetext{
${ }^{3}$ According to national legislation, politically sensitive data must not be directly linked to behavioral experimental data of identifiable persons. The questionnaire, containing sensitive political questions, was filled in by hand on paper, and only merged with the behavioral data after these were anonymized.

${ }^{4}$ Subjects were paid in local currency. USD exchange rate from 1 June 2017.

${ }^{5}$ Acceptance/approval letters, including full project description, are available upon request.
} 
are found in the online appendix, p. 4-10. The same experienced research assistant was used throughout the experiment, ensuring no effect was due to research assistant differences.

\section{Treatments}

The treatments consisted of fictive political news items consisting of 20 lines each (see an example in Figure 1), and treatments were presented in a per-subject random sequence. Only two subjects randomly ended up with identical treatment order. Subjects were instructed to read the texts thoroughly with a maximum of 5 minutes available for each text.

Figure 1: A: Example of one of the texts used in the experiment. Areas of interest are shown as numbered rectangles. B: Fixations for one subject are shown as circles and saccades as lines between fixations.

\section{A Klimapolitik: Nye tiltag mod klimaforandringer}

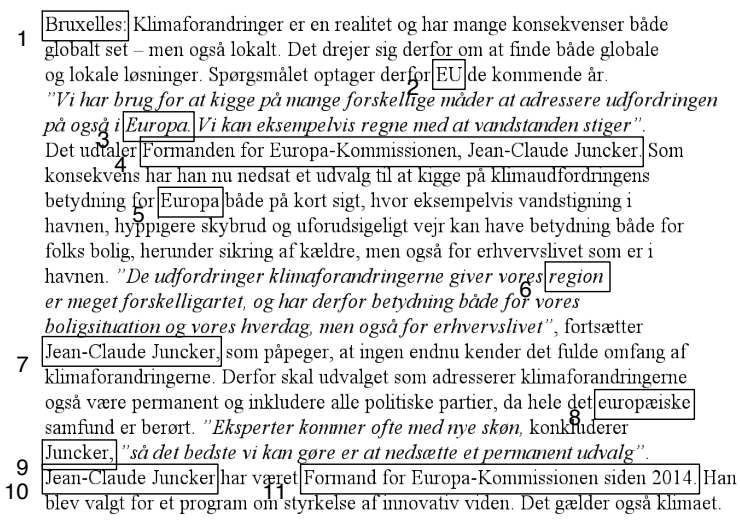

B

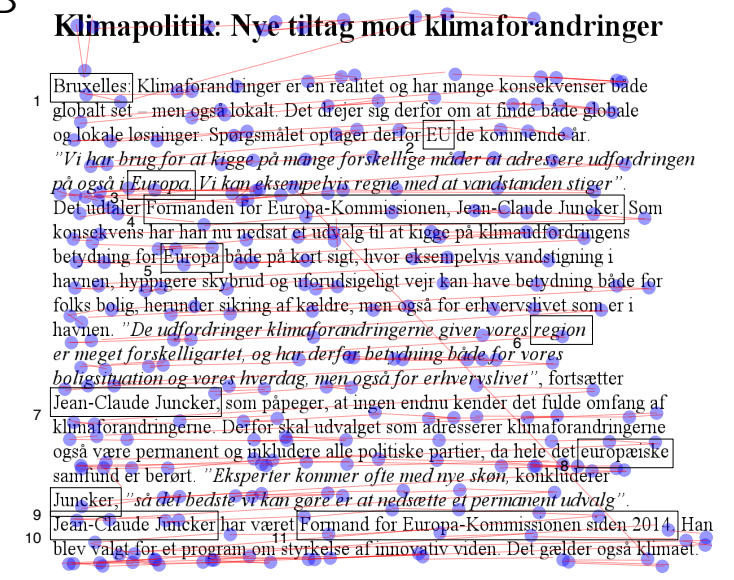

The six news treatments differed on governance institution as news source (local, national, and EU level) and news content (immigration and climate politics). Each treatment consisted of 11 different government institution cues (i.e. manipulations; shown as rectangular boxes in Figure 1A-B). These 11 cues were also our areas of interest (AOI), when measuring the experimental outcome, because we wanted to measure how different governance institutions affect fixations as a proxy for attention. The 11 AOI's (henceforth $\mathrm{AOI}_{1}-\mathrm{AOI}_{11}$ ) were placed identically across treatments so variation in position does not constitute a confound. Treatments also varied between two sets of news content, viz. immigration and climate policy, to control for robustness across governance institutions. For detailed treatment and experiment information, see the online appendix p. 4-10 and Table A4.

\section{Descriptive statistics of subjects}

Because the main questions addressed are political, we checked for potential political biases that could influence the results. Overall, the sample was balanced on an ideological left-right scale $(1=$ left $-10=$ right $)(\mathrm{M}=4.7 ; \mathrm{SD}=2.2)$, the degree to which they find politics salient $(0=$ not important $-5=$ very important $)(\mathrm{M}=3.1 ; \mathrm{SD}=0.9)$, and political trust $(0=$ no trust $-30=$ very high trust $)(\mathrm{M}=18.5 ; \mathrm{SD}=4.5) .^{6}$

Because reluctance towards EU integration is widespread in many EU countries, including Denmark (e.g. Nielsen, 2017), it may confound how governance institutions impact attention. We include a widely used question about support for European integration ( $1=$ EU integration

\footnotetext{
${ }^{6}$ By balanced, we refer to the same levels as observed in, for example, large-n surveys like Eurobarometer.
} 
Figure 2: Number of questions (Q1-Q3) correctly answered after reading each news text. $N=63$.

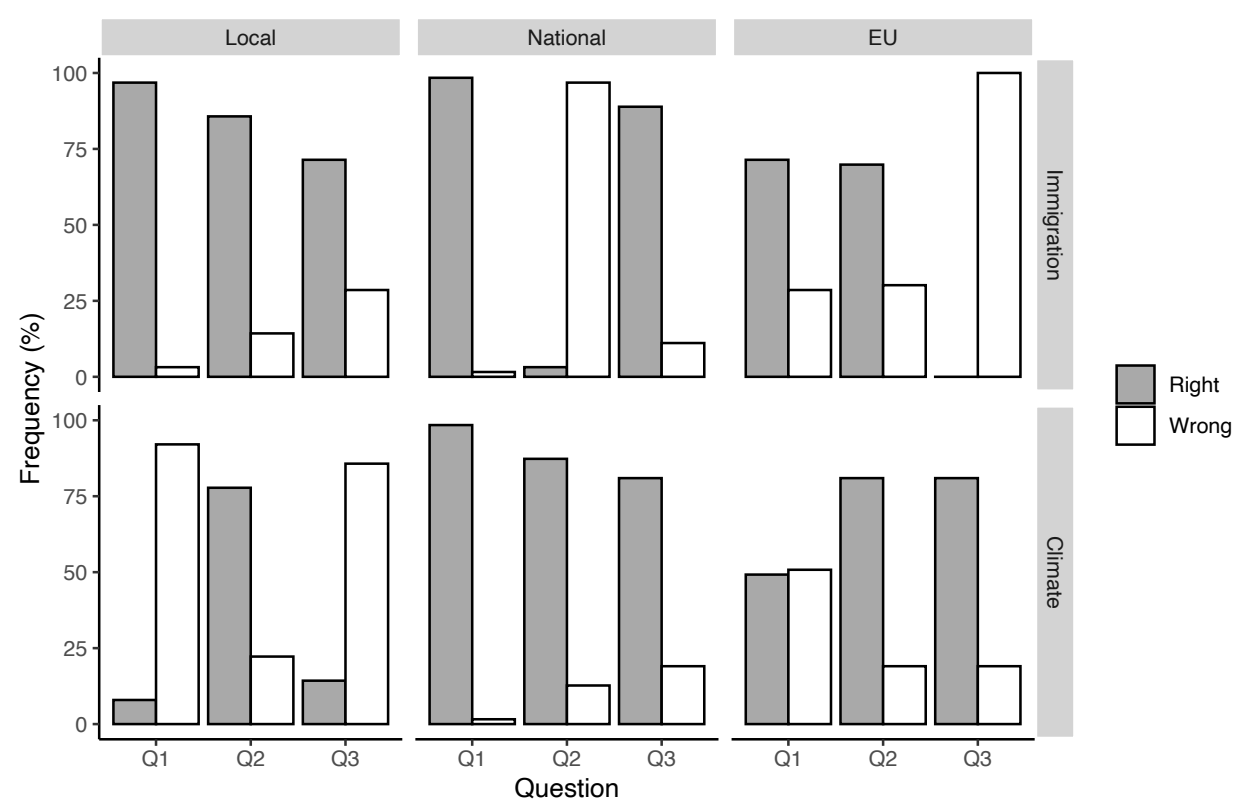

has gone too far $-10=\mathrm{EU}$ integration should go further $)(\mathrm{M}=6.3$; $\mathrm{SD}=2.3)$, resembling with minor deviation large- $N$ survey results when asking the same question (e.g. Nielsen, 2017).

The experimental manipulations include immigration and climate as policy topics. These topics are chosen because both figure high on the political agenda. To ensure these were indeed salient topics, and that being low on salience would not constitute a confounding factor, we asked subjects to rank the importance of immigration and climate policies $(0=$ little importance $-10=$ high importance). The immigration mean was $7.1(\mathrm{SD}=2.0)$, and the climate mean was $7.8(\mathrm{SD}=2.0)$.

Because subjects' news consumption and potential reading disabilities could affect the outcome (e.g. Rayner, 1998; Sears et al., 2010), we controlled for reading disabilities or diseases, affecting reading ability, for example, dyslexia. Two subjects reported reading disabilities. Subjects' political news consumption, including television, radio, internet and social media, was measured by an index $(4=$ very little news consumption $-16=$ very high levels of news consumption) with $(\mathrm{M}=9.4 ; \mathrm{SD}=2.5)$.

For detailed descriptive statistics see online appendix, Table A1.

\section{Comprehension check}

To ensure subjects had attentively read the experimental treatments, we included three posttreatment comprehension questions after each treatment. Each question was designed in such a way that subjects would not be able to answer them from "general" political knowledge. Figure 2 shows the frequency of correct and incorrect answers to each question in each treatment condition. While most treatments revealed a high percentage of correctly answered comprehension questions, we also see that question 2 in national-immigration treatment, question 3 in EU-immigration treatment, and question 1 and 3 in the local-climate treatment all have a majority of wrong answers. For the exact numbers reported in Figure 2, see online appendix, Table A3.

We test to what extent numbers of rightly answered questions impact our dependent variable (i.e. fixation in AOI). To do so, we added the number of correctly answered questions (up to $18, \mathrm{M}=11.6, \mathrm{SD}=1.6$, range: 7 to 15$)$ as a co-variate in a regression model. The number 
of correct answers has no significant effect on total fixation time ( $p=0.11$, see also Table 2 and Table 3), including no significant interaction with our main independent variables. While common practice when conducting comprehension or manipulation checks is to restrict estimates to subjects who understand or remember the experimental prompt, recent research, however, shows that this practice may lead to serious biases, arguing for a focus on what is revealed without discarding subjects (Aronow et al., 2019). Following this argumentation, as well as the fact that given our experimental design it does not make sense to leave out subjects on the basis of the comprehension check, we include all subjects. Yet, to ensure numbers of correctly answered questions do not have a significant effect on total fixation time, we include number of correct answers as a control in the analysis.

\section{Methods: eye tracking}

The study's outcome variable is measured using eye tracking, which — while not yet frequently used in political science - is becoming increasingly popular as an important methodological tool, that can help us understand media and political effects beyond insights gained by traditional methods (e.g. Dahmen, 2012). We use eye tracking to measure how attention might differ under exposure to different government institutions as news sources. We include one eye tracking position measure, viz. fixation time in AOI.

Figure 3: Total fixation time in each treatment. This includes all fixations, also those outside an AOI. Each point represents a single subject in a single treatment. Points have been spread horizontally by a small random amount to make all points visible. The line shows a linear regression with $95 \%$ CI given by the shaded band. It is seen that on average fixation time decreases with treatment number.

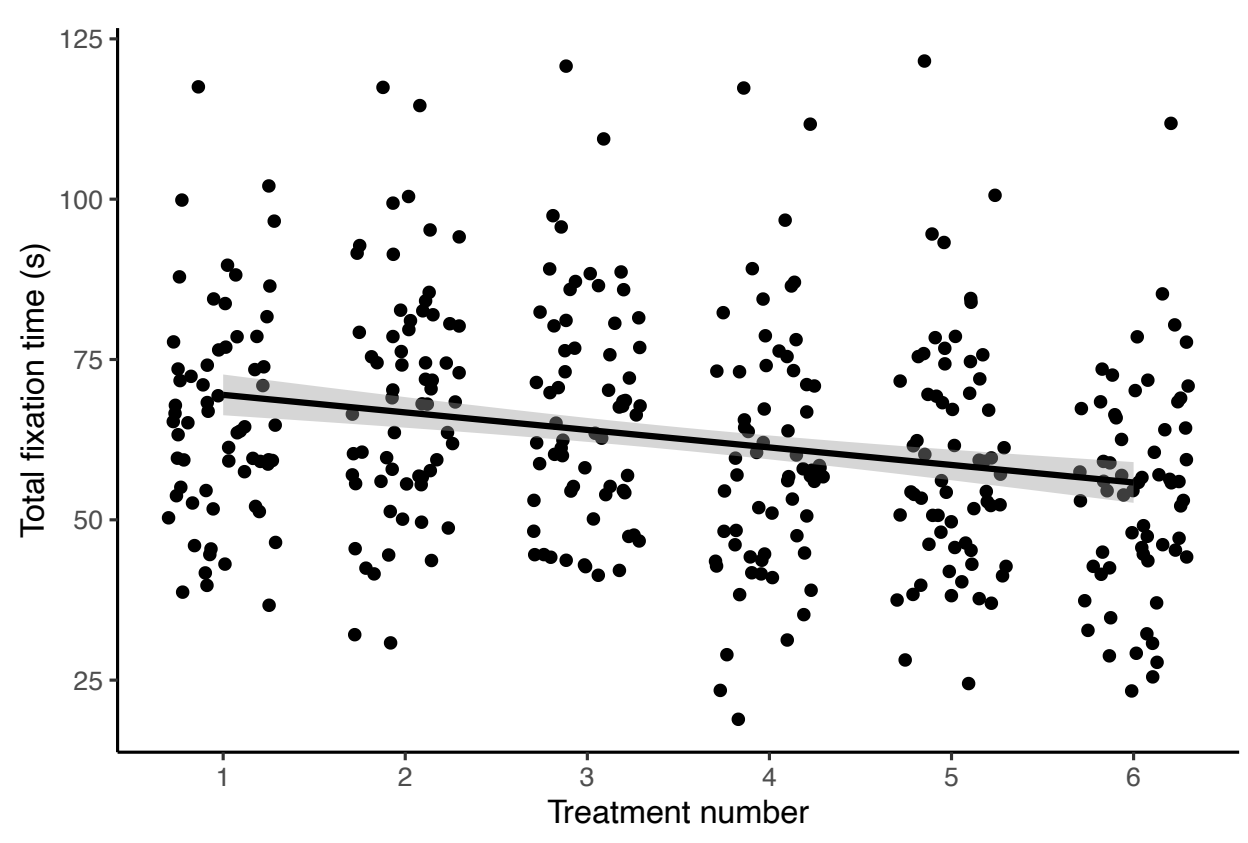

Fixations are one of the the primary eye movements components detected in eye tracking (Feng, 2011; Rayner, 1998), belonging to the most well-investigated indicators of cognitive processes used in many disciplines, including political science (e.g., Marquart et al., 2016). It is defined as a time period where the eye is relatively still during, for example, reading (Holmqvist et al., 2011, p. 377-389). While we cannot automatically take gaze as a proxy for cognition or attention (Feng, 2011), most research points to a strong connection between the two (Deubel 
et al., 1996; Just and Carpenter, 1976; Rayner, 1998), stipulating that there is basically no lag between fixation and brain processing (Just and Carpenter, 1980). Decoupling between attention and eye movements normally only occurs prior to a saccade, where attention shifts to a new location (Orquin and Loose, 2013). While fixations are ambiguous concepts to interpret (Holmqvist et al., 2011), longer fixations, referring to the exact AOI visit time from entry to exit, are associated with deeper processing, enhanced memory, and higher informativeness (Coronel and Sweitzer 2018; Holmqvist et al. 2011; Orquin and Loose 2013).

We use fixation time inside an AOI as a proxy for attention. It is operationalized as the fixation time in each AOI (in miliseconds), and a normalized version of this variable is constructed by dividing by the area of the AOI (in square pixels). More details are found in the online appendix, Table A5. Tests show significant sequential effect of treatment order 1-6 (Figure 3) and of AOI number (1-11) within each treatment (Figure 4). Hence, we include treatment sequence as a control in the analysis.

Figure 4: Normalized fixation time for each AOI. This figure shows fixation time divided by the area of each AOI. One point represents the normalized fixation time of a single subject in a single treatment and for the particular AOI indicated on the horizontal axis. Note: for clarity, the vertical axis is truncated at $0.5 \mathrm{~ms} / \mathrm{sq}$. pixel, leaving out 23 points that are above this value.

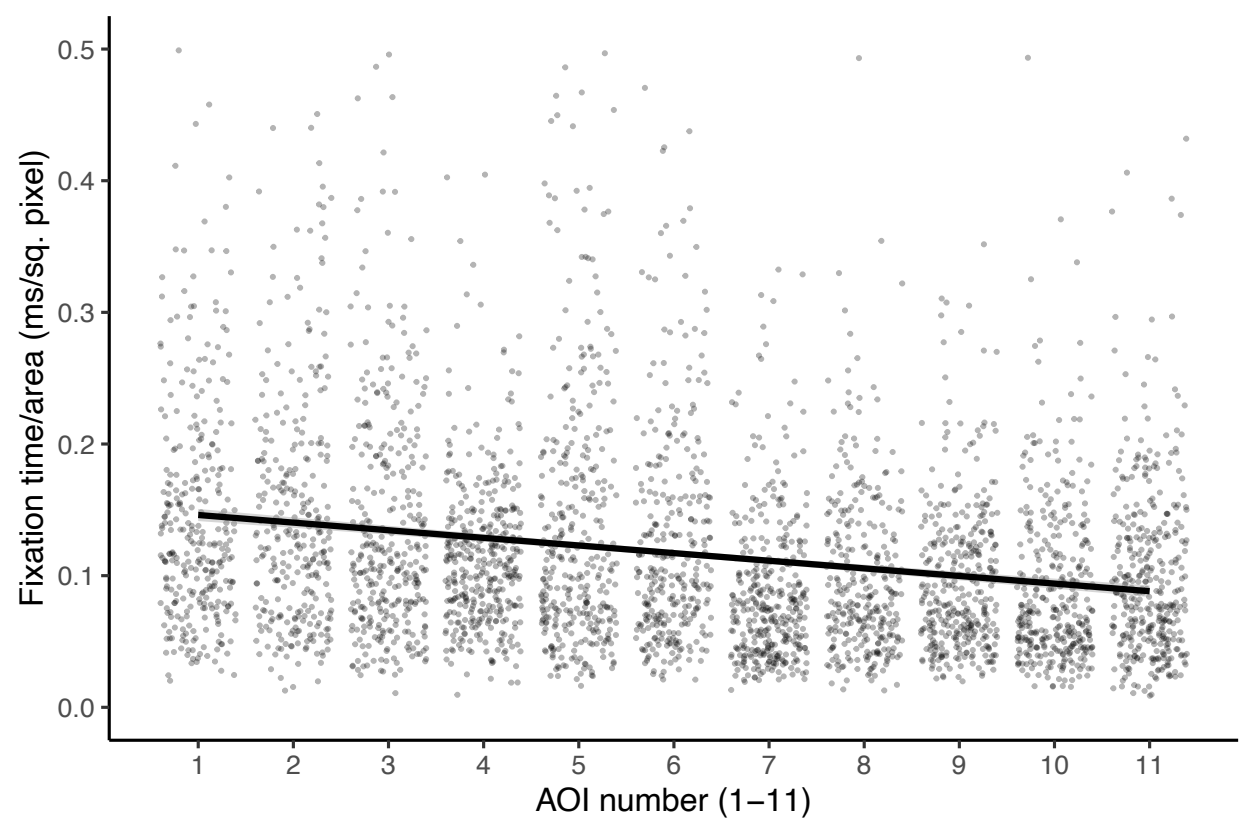

We used an SR Research EyeLink 1000 with a desk-mounted chin rest. Following the reporting standards by Fiedler et al. (2019), we included further details about eye tracking equipment and software in Table A5 in the online appendix. Data were imported using the $\mathrm{R}$ package iTrackr (Hubbard, 2015).

\section{Results: Governance institution and attention}

The outcome variable, normalized fixation time, is shown in Table 1 as the total fixation time in each treatment divided by the total area of all AOI's. As seen, mean fixation time in the EU treatments are longer than mean fixation time in the national and local treatments.

To test if attention to political news significantly differs according to governance institutions, we performed a Generalized Linear Mixed-Effects (GLME) model analysis of the relationship 
Table 1: Mean and standard deviation of the total fixation time (in milliseconds) in all AOIs divided by the total AOI area (in square pixels) for each of the six treatments.

\begin{tabular}{|c|c|c|c|c|}
\hline \multirow[t]{2}{*}{ Treatment } & \multirow[t]{2}{*}{ Topic } & \multirow[t]{2}{*}{$\begin{array}{l}\text { Governance } \\
\text { institution }\end{array}$} & \multicolumn{2}{|c|}{$\begin{array}{l}\text { Fixation time } \\
\text { (ms/sq. pixel) }\end{array}$} \\
\hline & & & $\mathrm{M}$ & SD \\
\hline 1 & Immigration & Local & 0.107 & 0.035 \\
\hline 2 & Immigration & National & 0.095 & 0.036 \\
\hline 3 & Immigration & EU & 0.114 & 0.030 \\
\hline 4 & Climate & Local & 0.100 & 0.032 \\
\hline 5 & Climate & National & 0.106 & 0.036 \\
\hline 6 & Climate & $\mathrm{EU}$ & 0.110 & 0.040 \\
\hline
\end{tabular}

between fixation time and governance institution. The analysis was performed in $\mathrm{R}$ ( $\mathrm{R}$ Core Team, 2020) using the lme4 package (Bates et al., 2015). Since fixation time is distributed according to an exponential distribution, we applied a logarithmic link function. We tested several models (see Table 2), which all included the independent variables governance level and news topic which are the factors in our $3 \times 2$ factorial design. Since both factors are within subject, we included random intercepts for subject, and since we performed repeated trials and repeated measures within each treatment (AOI's), we also included random intercepts for treatment number and AOI number. These random intercepts model the negative slopes seen in Figure 3 and 4 in the GLME model, taking into account that the multiple measures are dependent. As noted previously, we include the number of correct answers to the comprehension questions as a control.

Answering H1, model 1-4 in Table 2 consistently show only a significant effect of the EU governance institution relative to the local level. Crucially, this effect is positive contrary to our expectations. Second, in H2, we expected support for European integration to play a role for attention, just like we expected differences according to sex, albeit the latter was not stated in an explicit hypothesis. Including these two variables as covariates in model 3-4 of Table 2 nevertheless show no significant effect. Hence, we do not find support for H2.

Even though we do not find any significant effect of the news topic in Table 2, in accordance with our expectations in H3, there may be an interaction effect between governance institution and news topic. Consequently, we included an interaction term (model 2 and 4 in Table 2). An ANOVA test shows that the interactions in model $2(p=0.0033)$ and in model $4(p=0.0032)$ are significant. The results for model 4 are shown in Table 3. The type II ANOVA test in Table 3 showed a main effect of governance institution $\left(p<10^{-14}\right)$, and a significant interaction between governance level and news topic $(p=0.0032)$. No other variables had significant effects.

Lastly, to consolidate our results, a post hoc test of differences was performed using the package emmeans (Lenth, 2020). The results in Table 4 show no difference between local and national governance institutions, but the EU level is different from both local and national. The model-estimated marginal means are shown in Figure 5. Here the interaction between governance institution and news topic can be inferred from the slope of the curve corresponding to the national governance institution. 
Table 2: Generalized linear mixed effects models of fixation time (exponentially distributed).

\begin{tabular}{|c|c|c|c|c|}
\hline & \multicolumn{4}{|c|}{ Fixation time } \\
\hline & $(1)$ & $(2)$ & (3) & (4) \\
\hline National level & $\begin{array}{l}-0.033 \\
(0.023)\end{array}$ & $\begin{array}{c}-0.105^{* * *} \\
(0.032)\end{array}$ & $\begin{array}{l}-0.032 \\
(0.023)\end{array}$ & $\begin{array}{c}-0.105^{* * *} \\
(0.032)\end{array}$ \\
\hline EU level & $\begin{array}{c}0.145^{* * *} \\
(0.023)\end{array}$ & $\begin{array}{c}0.130^{* * *} \\
(0.032)\end{array}$ & $\begin{array}{c}0.145^{* * *} \\
(0.023)\end{array}$ & $\begin{array}{c}0.130^{* * *} \\
(0.032)\end{array}$ \\
\hline Topic Climate & $\begin{array}{l}-0.014 \\
(0.019)\end{array}$ & $\begin{array}{c}-0.073^{* *} \\
(0.032)\end{array}$ & $\begin{array}{l}-0.014 \\
(0.019)\end{array}$ & $\begin{array}{c}-0.073^{* *} \\
(0.032)\end{array}$ \\
\hline Correct answers & $\begin{array}{l}-0.033 \\
(0.021)\end{array}$ & $\begin{array}{l}-0.033 \\
(0.021)\end{array}$ & $\begin{array}{l}-0.034 \\
(0.021)\end{array}$ & $\begin{array}{l}-0.034 \\
(0.021)\end{array}$ \\
\hline National level * Topic Climate & & $\begin{array}{c}0.145^{* * *} \\
(0.045)\end{array}$ & & $\begin{array}{c}0.145^{* * *} \\
(0.045)\end{array}$ \\
\hline EU level * Topic Climate & & $\begin{array}{c}0.030 \\
(0.046)\end{array}$ & & $\begin{array}{c}0.030 \\
(0.046)\end{array}$ \\
\hline Sex male & & & $\begin{array}{l}-0.063 \\
(0.064)\end{array}$ & $\begin{array}{r}-0.063 \\
(0.065)\end{array}$ \\
\hline Euroscepticism & & & $\begin{array}{l}-0.001 \\
(0.014)\end{array}$ & $\begin{array}{l}-0.002 \\
(0.014)\end{array}$ \\
\hline Constant & $\begin{array}{c}-1.817^{* * *} \\
(0.259)\end{array}$ & $\begin{array}{c}-1.788^{* * *} \\
(0.259)\end{array}$ & $\begin{array}{c}-1.771^{* * *} \\
(0.286)\end{array}$ & $\begin{array}{c}-1.739^{* * *} \\
(0.286)\end{array}$ \\
\hline $\mathrm{N}$ & 3,741 & 3,741 & 3,741 & 3,741 \\
\hline Log Likelihood & $5,313.094$ & $5,318.823$ & $5,313.582$ & $5,319.315$ \\
\hline AIC & $-10,608.190$ & $-10,615.650$ & $-10,605.160$ & $-10,612.630$ \\
\hline $\mathrm{BIC}$ & $-10,552.140$ & $-10,547.150$ & $-10,536.670$ & $-10,531.680$ \\
\hline
\end{tabular}

${ }^{*} \mathrm{p}<.1 ;{ }^{* *} \mathrm{p}<.05 ;{ }^{* *} \mathrm{p}<.01$. Local level serves as baseline for governance level

\section{Discussion and Conclusion}

This manuscript provides experimental evidence of a governance institution effect on attention to political news, holding political news content constant. More precisely, using data from an eye tracking experiment $(N=63)$, our study provides three important insights. First, we find that attention (i.e. eye fixation) is significantly linked to governance institution. Yet, contrary to our expectations, subjects' fixation time is significantly longer for EU institutions vis-a-vis national and local institutions. Second, also contrasting our expectations, we find that this relationship is not impacted by subjects' attitudes towards EU integration. Third, while we find a robust effect of governance institution across news topics, we also find a significant interaction effect between topic and governance institution, inferring that indeed topic matters for attention when exposed to certain governance institutions. Our findings advances scholarship in at least two ways. First, as far as we are aware, we are first to provide empirical evidence of a significant governance institution effect on attention, which is disentangled from news topic. While the relationship between governance institution and news topic is complex, as our finding of an interaction between the two also shows, we are nevertheless able to estimate, for the first time, the isolated effect of governance institutions on political attention. Second, we provide a methodological contribution to the study of democratic institutions and political news. With eye tracking, we are able to assess components of decision-making, judgment and attention that has hitherto been endogenous to the political decision-making process. While eye tracking is not a new tool in political science, it is still underutilized in our view. 
Table 3: ANOVA corresponding to model 4 in table 2.

\begin{tabular}{lrrr}
\hline & $\chi^{2}$ & Df & $\operatorname{Pr}\left(>\chi^{2}\right)$ \\
\hline Governance level & 68.53 & 2 & 0.0000 \\
Topic & 0.60 & 1 & 0.4403 \\
Correct answers & 2.59 & 1 & 0.1074 \\
Sex & 0.96 & 1 & 0.3267 \\
Euroscepticism & 0.01 & 1 & 0.9151 \\
Level * Topic & 11.47 & 2 & 0.0032 \\
\hline
\end{tabular}

Table 4: Pairwise differences for model 4 in Table 2. Results are given on a logarithmic scale. The Tukey method has been used to adjust $p$-values.

\begin{tabular}{lrrrr}
\hline Contrast & Estimate & SE & $z$-ratio & $p$-value \\
\hline Local - National & 0.03 & 0.02 & 1.44 & 0.32 \\
Local - EU & -0.14 & 0.02 & -6.34 & 0.00 \\
National - EU & -0.18 & 0.02 & -7.75 & 0.00 \\
Immigration - Climate & 0.01 & 0.02 & 0.77 & 0.44 \\
\hline
\end{tabular}

Notwithstanding our finding of a clear effect of government institution and attention, it turned out to be in the opposite direction of our hypothesis, H1. We believe, in hindsight, that the most likely cause of this, lies not with an erroneous theoretical prediction of our hypothesis, but rather with a fault in our experimental design. By telling subjects that they would be quizzed on the news items they read, we inadvertently created an experimenter demand effect. Our treatments, including the follow up comprehension questions, were built in such a way that it could alter individuals' normal reading and attention patterns. Many people find EU-related news complex, and that might have enhanced the fixation time since they knew they would have to answer questions about the EU after the treatment. We think it is important to shed light on these challenges, which may also effect the external or mundane validity of the study. In sum, we need to continue our methodological development of a better measurement link between the complex eye-mind relationship as well as develop increasingly more sophisticated methods and designs to avoid, for example, experimenter demands. And we here encourage the use of eye tracking as an integrated component of a multi-methodological research design.

The findings of the study open up new questions about the role of governance institutions in political decision-making. We find a significant interaction effect between topic and governance institution, inferring that indeed topic matters for attention to certain governance institutions. This raises the question; would a different salient political content than immigration and climate have produced a different outcome? Also, while we here did not address the role of news framing when exposed to political news, it nevertheless remains very relevant to ask if the effect of news framing differs according to governance institutions? Is negative news perceived in different ways according to governance institutions? Lastly, while this study benefited from the advantages obtained in the experimental lab, it would be interesting to see to what extent governance institution play a role when studying them outside the lab, including expanding the subject pool beyond the convenient student sample.

Only imagination and technology limit the potential use of eye tracking methodology. While we have explored how governance institution plays a role for attention while reading political 
Figure 5: Model-estimated marginal means with 95\% confidence intervals.

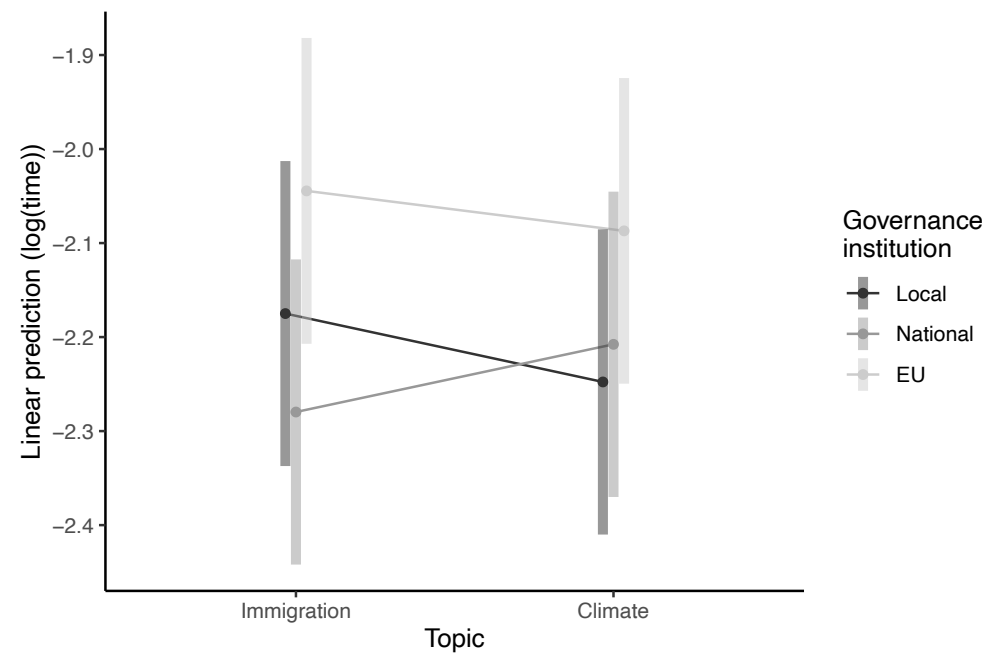

news, it still remains to place these findings in a broader context, determining its role in political opinion formation and actual political behavior.

\section{References}

Aronow, P. M., Baron, J. and Pinson, L. (2019), 'A note on dropping experimental subjects who fail a manipulation check', Political Analysis 27(4), 572-589.

Bates, D., Mächler, M., Bolker, B. and Walker, S. (2015), 'Fitting linear mixed-effects models using lme4', Journal of Statistical Software 67(1), 1-48.

Blom-Hansen, J., Elklit, J., Serritzlew, S. and Villadsen, L. R. (2016), 'Ballot position and election results: Evidence from a natural experiment', Electoral Studies 44, 172-183.

Bode, L., Vraga, E. K. and Troller-Renfree, S. (2017), 'Skipping politics: Measuring avoidance of political content in social media', Research \& Politics 4(2), 2053168017702990.

Boomgaarden, H. G., Schuck, A. R., Elenbaas, M. and De Vreese, C. H. (2011), 'Mapping eu attitudes: Conceptual and empirical dimensions of euroscepticism and eu support', European Union Politics 12(2), 241-266.

Bundesen, C. and Habekost, T. (2008), Principles of Visual Attention: Linking Mind and Brain, Oxford University Press Oxford.

Chong, D. and Druckman, J. N. (2007), 'Framing public opinion in competitive democracies', American Political Science Review 101(4), 637-655.

Coronel, J. C. and Sweitzer, M. D. (2018), 'Remembering political messages in dynamic information environments: Insights from eye movements', Human Communication Research 44(4), 374-398.

Dahmen, N. S. (2012), 'Photographic Framing in the Stem Cell Debate: Integrating EyeTracking Data for a New Dimension of Media Effects Research', Americal Behavioral Scientist 56(2), 189-203. 
De Vreese, C. H. (2001), 'Europe in the news: A cross-national comparative study of the news coverage of key EU events', European Union Politics 2(3), 283-307.

De Vreese, C. H. et al. (2003), Framing Europe: television news and European integration, Aksant Amsterdam.

Deubel, H., Schneider, W. X. et al. (1996), 'Saccade target selection and object recognition: Evidence for a common attentional mechanism', Vision research 36(12), 1827-1838.

Druckman, J. N. and Kam, C. D. (2011), Students as experimental participants, in J. Druckman, D. P. Greene, J. H. Kuklinski and A. Lupia, eds, 'Cambridge Handbook of Experimental Political Science', Vol. 1, Cambridge University Press New York, chapter 4, pp. 41-57.

Feng, G. (2011), 'Eye tracking: A brief guide for developmental researchers', Journal of Cognition and Development 12(1), 1-11.

Festinger, L. (1962), A theory of cognitive dissonance, Vol. 2, Stanford university press.

Fiedler, S., Schulte-Mecklenbeck, M., Renkewitz, F. and Orquin, J. L. (2019), Increasing reproducibility of eye-tracking studies, in M. Schulte-Mecklenbeck, A. Kuehberger and J. G. Johnson, eds, 'A Handbook of Process Tracing Methods', Routledge, p. 65.

Gerber, A., Arceneaux, K., Boudreau, C., Dowling, C., Hillygus, S., Palfrey, T., Biggers, D. R. and Hendry, D. J. (2014), 'Reporting guidelines for experimental research: A report from the experimental research section standards committee', Journal of Experimental Political Science 1(1), 81-98.

Guazzini, A., Yoneki, E. and Gronchi, G. (2015), 'Cognitive dissonance and social influence effects on preference judgments: An eye tracking based system for their automatic assessment', International journal of human-computer studies 73, 12-18.

Harmon-Jones, E. and Mills, J. (2019), An introduction to cognitive dissonance theory and an overview of current perspectives on the theory, in E. Harmon-Jones, ed., 'Cognitive dissonance: Reexamining a pivotal theory in psychology, 2nd ed', American Psychological Association, Washington, DC, US, pp. 3-24.

Hobolt, S. B. (2016), 'The brexit vote: a divided nation, a divided continent', Journal of European Public Policy 23(9), 1259-1277.

Holmqvist, K., Nyström, M., Andersson, R., Dewhurst, R., Jarodzka, H. and Van de Weijer, J. (2011), Eye tracking: A comprehensive guide to methods and measures, Oxford University Press.

Hubbard, J. (2015), itrackR - eyetracking analysis. R package version 0.9.

Hutchings, V. L. and Jardina, A. E. (2009), 'Experiments on racial priming in political campaigns', Annual Review of Political Science 12, 397-402.

Just, M. A. and Carpenter, J. P. (1980), 'A theory of reading: From eye fixations to comprehension', Psychological Review 87(4), 329-354.

Just, M. A. and Carpenter, P. A. (1976), 'Eye Fixations and Cognitive Processes', Cognitive Psychology 8(441-480). 
Krupnikov, Y. and Levine, A. S. (2014), 'Cross-sample comparisons and external validity', Journal of Experimental Political Science 1(1), 59-80.

Lenth, R. (2020), emmeans: Estimated Marginal Means, aka Least-Squares Means. R package version 1.4.6.

URL: https://CRAN.R-project.org/package=emmeans

Marquart, F., Matthes, J. and Rapp, E. (2016), 'Selective exposure in the context of political advertising: A behavioral approach using eye-tracking methodology', International Journal of Communication 10, 20.

McDermott, R. (2011), Internal and external validity, in J. Druckman, D. P. Greene, J. H. Kuklinski and A. Lupia, eds, 'Cambridge Handbook of Experimental Political Science', Cambridge University Press Cambridge, chapter 3, pp. 27-40.

Morton, R. B. and Williams, K. C. (2010), Experimental Political Science and the Study of Causality: From Nature to the Lab, Cambridge University Press, New York.

Mudde, C. and Kaltwasser, C. R. (2012), Populism in Europe and the Americas: Threat or corrective for democracy?, Cambridge University Press.

Mummolo, J. and Peterson, E. (2019), 'Demand effects in survey experiments: An empirical assessment', American Political Science Review 113(2), 517-529.

Nielsen, J. H. (2017), The Pragmatic Euroscepticism of Scandinavia, in S. Usherwood and N. Startin, eds, 'Routledge Handbook of Euroscepticism', Routledge, chapter 18, pp. 231-242.

Nielsen, J. H. (2018), 'The effect of affect: How affective style determines attitudes towards the eu', European Union Politics 19(1), 75-96.

Nielsen, J. H. and Franklin, M. N. (2017), The Eurosceptic 2014 European Parliament Elections: Second Order or Second Rate?, Palgrave European Union Series, Palgrave Macmillan, London.

Norris, P. (2011), Democratic Deficit: Critical Citizens Revisited, Cambridge University Press.

Orquin, J. L. and Loose, S. M. (2013), 'Attention and choice: A review on eye movements in decision making', Acta Psychologica 144(1), 190-206.

R Core Team (2020), R: A Language and Environment for Statistical Computing, R Foundation for Statistical Computing, Vienna, Austria.

URL: https://www.R-project.org/

Rayner, K. (1998), 'Eye movements in reading and information processing: 20 years of research.', Psychological Bulletin 124(3), 372.

Schiessl, M., Duda, S., Thölke, A. and Fischer, R. (2003), 'Eye tracking and its application in usability and media research', MMI-interaktiv Journal 6(2003), 41-50.

Sears, C. R., Thomas, C. L., LeHuquet, J. M. and Johnson, J. C. S. (2010), 'Attentional biases in dysphoria: An eye-tracking study of the allocation and disengagement of attention', Cognition and Emotion 24(8), 1349-1368.

Sülflow, M., Schäfer, S. and Winter, S. (2019), 'Selective attention in the news feed: An eye-tracking study on the perception and selection of political news posts on facebook', New Media \& Society 21(1), 168-190. 
Tatler, B. W., Kirtley, C., Macdonald, R. G., Mitchell, K. M. and Savage, S. W. (2014), The active eye: Perspectives on eye movement research, in M. Hosley, M. Eliot, B. A. Knight and R. Reilly, eds, 'Current Trends in Eye Tracking Research', Springer, chapter 1, pp. 3-16.

Viviani, P. (1990), 'Eye movements in visual search: Cognitive, perceptual, and motor control aspects', Rev Oculomot Res. 4, 353-383.

Vraga, E., Bode, L. and Troller-Renfree, S. (2016), 'Beyond self-reports: Using eye tracking to measure topic and style differences in attention to social media content', Communication Methods and Measures 10(2-3), 149-164.

Zizzo, D. J. (2010), 'Experimenter demand effects in economic experiments', Experimental Economics 13(1), 75-98. 


\section{Online Appendix: In the Eye of the Beholder: Using Eye Tracking to Understand the Causal Influence of Governance Institutions on Attention}

\section{Descriptive statistics}

Details about the subjects in the study are shown in Table A.1 and Table A.2.

Table A.1: Descriptive statistics of variables in the study, excluding dependent variables.

\begin{tabular}{|c|c|c|c|c|}
\hline Concept & Variable/survey item & Descriptive statistics & Mean (SD) & $\mathbf{N}$ \\
\hline Sex & $\begin{array}{l}\text { Dichotomous. } 0=\text { male; } 1= \\
\text { female }\end{array}$ & $\begin{array}{l}\text { Dichotomous. } \\
29 \text { males; } 34 \text { females }\end{array}$ & & \\
\hline Age & Interval. & Range between 18-48 & $24.7(2.64)$ & 63 \\
\hline $\begin{array}{l}\text { Political } \\
\text { activity } \\
\text { index }\end{array}$ & $\begin{array}{l}\text { Within which of the following } \\
\text { political areas have you been } \\
\text { politically active in the past } 12 \\
\text { months (e.g. signed a petition, } \\
\text { taken part in a demonstration, } \\
\text { contacted a politician or taken } \\
\text { part in some other form of } \\
\text { political protest? Answer } \\
\text { categories: } 1=\text { EU area; } 2= \\
\text { National politics; } 3=\text { Municipal } \\
\text { politics; } 4=\text { Have not been } \\
\text { politically active) }\end{array}$ & $\begin{array}{l}\text { Dichotomous. } \\
0=\text { Did not participate; } \\
1=\text { Did participate. } \\
\text { Activity index is an interval } \\
\text { accumulative variable, consisting } \\
\text { of } 4 \text { categories: } \\
1=\text { Not active at all; } \\
2=\text { Active at } 1 \text { level; } \\
3=\text { Active at } 2 \text { levels; } \\
4=\text { Active at } 3 \text { levels }\end{array}$ & $0.6(1.03)$ & 63 \\
\hline $\begin{array}{l}\text { Political } \\
\text { salience }\end{array}$ & $\begin{array}{l}\text { Please say how important politics } \\
\text { is in your life? }\end{array}$ & $\begin{array}{l}\text { Interval. } \\
0=\text { Not important }- \\
5=\text { Very important }\end{array}$ & $3.1(0.9)$ & 62 \\
\hline Ideology & $\begin{array}{l}\text { In political matters, people talk } \\
\text { of "the left" and "the right" How } \\
\text { would you place your views on } \\
\text { this scale generally speaking? ( } 1 \\
=\text { Left }-10=\text { Right) }\end{array}$ & $\begin{array}{l}\text { Interval. } \\
1=\text { Left }-10=\text { Right }\end{array}$ & $4.7(2.2)$ & 60 \\
\hline
\end{tabular}


Table A.1: Descriptive statistics of variables in the study, excluding dependent variables.

\begin{tabular}{|c|c|c|c|c|}
\hline Concept & Variable/survey item & Descriptive statistics & Mean (SD) & $\mathbf{N}$ \\
\hline $\begin{array}{l}\text { Political } \\
\text { trust index }\end{array}$ & $\begin{array}{l}\text { How much do you trust each of } \\
\text { the following institution? You } \\
\text { are asked to answer on a scale of } \\
0 \text { to } 10 \text {, where } 0 \text { means that you } \\
\text { have no trust at all in the } \\
\text { institution and } 10 \text { means that } \\
\text { you have very much trust }\end{array}$ & $\begin{array}{l}\text { Interval. } \\
\text { Answer categories: } \\
1=\text { EU level; } \\
2=\text { State level; } \\
3=\text { Municipality level; } \\
4=\text { Don't know. } \\
\text { Political trust index is created } \\
\text { by merging the three governance } \\
\text { levels into one index variable }(0 \\
=\text { No trust at all }-30=\text { Very } \\
\text { high trust })\end{array}$ & $18.5(4.5)$ & 60 \\
\hline $\begin{array}{l}\text { Salience of } \\
\text { immigration } \\
\text { policy }\end{array}$ & $\begin{array}{l}\text { We want to know how important } \\
\text { immigration policy is for you. } \\
\text { On a scale from } 0 \text { to } 10 \text { where } 0 \\
\text { means immigration policy is of } \\
\text { very little importance to me and } \\
10 \text { means of very high } \\
\text { importance to me }\end{array}$ & $\begin{array}{l}\text { Interval. } \\
0=\text { Little importance }- \\
10=\text { High importance }\end{array}$ & $7.1(2.0)$ & 63 \\
\hline $\begin{array}{l}\text { Salience of } \\
\text { climate } \\
\text { policy }\end{array}$ & $\begin{array}{l}\text { We want to know how important } \\
\text { climate policy is for you. On a } \\
\text { scale from } 0 \text { to } 10 \text { where } 0 \text { means } \\
\text { climate policy is of little } \\
\text { importance to me and } 10 \text { means } \\
\text { of very high importance to me }\end{array}$ & $\begin{array}{l}\text { Interval. } \\
0=\text { Little importance }- \\
10=\text { High importance }\end{array}$ & $7.8(2.00)$ & 63 \\
\hline $\begin{array}{l}\text { Political } \\
\text { news } \\
\text { consumption } \\
\text { index }\end{array}$ & $\begin{array}{l}\text { How often do you consult } \\
\text { political news in the following } \\
\text { media? (Television, Radio, the } \\
\text { internet and social media) }\end{array}$ & $\begin{array}{l}\text { Interval. } \\
\text { (1) Less than weekly; (2) weekly } \\
\text { (3) Daily (4) Many times daily. } \\
\text { All four news categories merged } \\
\text { into one index variable, ranging } \\
\text { from } 4=\text { Very little news } \\
\text { consumption to } 16=\text { Very high } \\
\text { levels of news consumption. }\end{array}$ & $9.4(2.5)$ & 62 \\
\hline $\begin{array}{l}\text { Euroscepti- } \\
\text { cism }\end{array}$ & $\begin{array}{l}\text { Some say that European } \\
\text { integration should go further } \\
\text { while others say it has already } \\
\text { gone too far. On a scale from } 1 \text {, } \\
\text { which means that European } \\
\text { integration has gone too far and } \\
\text { 10, which means that European } \\
\text { integration should go further } \\
\text { what do you think? }\end{array}$ & $\begin{array}{l}\text { Interval. } \\
1=\text { European integration has } \\
\text { gone too far }-10=\text { European } \\
\text { integration should go further }\end{array}$ & $6.3(2.3)$ & 63 \\
\hline $\begin{array}{l}\text { Reading } \\
\text { disabilities }\end{array}$ & $\begin{array}{l}\text { Do you suffer from any illness } \\
\text { that affect your ability to read, } \\
\text { for example dyslexic? }\end{array}$ & $\begin{array}{l}\text { Dichotomous. } \\
N=2 \text { (yes) } \\
N=61 \text { (No) }\end{array}$ & & 63 \\
\hline
\end{tabular}


Table A.2: Main subject of study. The recruited subjects were all students. This table shows their self-reported main study subject.

\begin{tabular}{lrrr}
\cline { 1 - 1 } Subject of study & & \multicolumn{2}{c}{ Frequency } \\
\cline { 1 - 1 } Economics/business & & 17 & $(27.0 \%)$ \\
Political Science & & 8 & $(12.7 \%)$ \\
Communication & & 6 & $(9.5 \%)$ \\
Linguistics & & 4 & $(6.3 \%)$ \\
Biology & & 3 & $(4.8 \%)$ \\
Drama & 3 & $(4.8 \%)$ \\
Cultural studies & & 2 & $(3.2 \%)$ \\
Psychology & & 2 & $(3.2 \%)$ \\
Anthropology & & 1 & $(1.6 \%)$ \\
English & & 1 & $(1.6 \%)$ \\
Physiotherapy & & $(1.6 \%)$ \\
History & & 1 & $(1.6 \%)$ \\
Engineering & & 1 & $(1.6 \%)$ \\
Journalism & & 1 & $(1.6 \%)$ \\
Cognitive Science & & 1 & $(1.6 \%)$ \\
Chef & & 1 & $(1.6 \%)$ \\
Laboratory Technician & 1 & $(1.6 \%)$ \\
Teacher & 1 & $(1.6 \%)$ \\
Mathematics & & $(1.6 \%)$ \\
Medicine & 1 & $(1.6 \%)$ \\
Musicology & 1 & $(1.6 \%)$ \\
Social Science & 1 & $(1.6 \%)$ \\
Science & 1 & $(1.6 \%)$ \\
Public Health & 1 & $(1.6 \%)$ \\
Nursing & 1 & $(1.6 \%)$ \\
Education Science & 1 & $(1.6 \%)$ \\
\hline Total & 63 & $(100 \%)$ \\
\hline
\end{tabular}




\section{Experimental treatment and comprehension questions}

The texts used in the experimental treatments are given verbatim in the sections $2.1-2.6$. The numbers of correct and wrong answers for each question are summarized in Table A.3. An overview of the whole experiment from beginning to end is provided in Table A.4.

Each Area of Interest text is emphasized in bold here, but was not highlighted in the original stimulus (see Figure 1 in the article for a screenshot). The comprehension questions were randomized between subjects. Each screen showed one question only. The right answer in the three comprehension questions is emphasized here in bold (again this was not the case when viewed by subjects). Each treatment is 20 lines, same font and size.

\subsection{TEXT 1: IMMIGRATION POLITICS AT THE LOCAL LEVEL}

\section{Immigration: Nytilkomne skaber nye udfordringer}

Århus: Allerede tidligt torsdag morgen forrige uge stod det klart, at den stigende indvandring, herunder også et stigende antal asylansøgere fra borgerkrigen i Syrien, også vil have konsekvenser for kommunen de kommende år. "Tallene er fortsat meget høje, og vi har så stor en gruppe af indvandrere, som kom til kommunen $i 2016$ og helt tilbage $i$ 2015, som stadig mangler bolig". Det udtaler Århus Borgmester Jacob Bundsgaard (Socialdemokratiet) . Som konsekvens har han nu nedsat et udvalg til at kigge på immigrationsudfordringens betydning for Århus Kommune både på kort sigt, hvor boligmanglen og de mange ressourcer til sagsbehandling pt. topper agendaen, men også på lang sigt, hvor særlige integrationsindsatser skal strømlines til de forskellige typer migranter og flygtninge. "De flygtninge og indvandrere som kommer til vores kommune kommer fra meget forskellige baggrunde og har vidt forskellige præmisser for at blive integreret godt i vores samfund og på vores arbejdspladser", fortsætter Jacob Bundsgaard, som understreger, at god integration ikke kun handler om integration på arbejdsmarkedet. Nytilkomne udlændinge skal også forstå vores

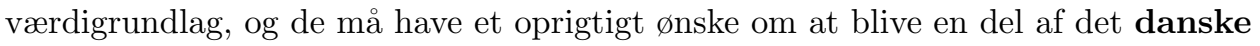
samfund også værdimæssigt. "Men når alt kommer til alt", konkluderer Bundsgaard, "så er succesraten for integration bundet op på arbejdsmarkedet". Jacob Bundsgaard har siddet som Borgmester i Århus siden 2011. Han kan ikke erindre, at der har været en tilsvarende krise på højde med denne tidligere.

Question 1: Hvilket parti kommer Jacob Bundsgaard fra? (sct kun et kryds)

1. Socialdemokratiet:

2. Venstre:

3. Løsgænger (uden partitilhørsforhold):

4. Socialistisk Folkeparti:

Question 2: Hvilken måde integreres flygtninge og indvandrere bedst ifølge teksten? (sct kun et kryds)

1. Ved at deltage aktivt i de aktiviteter kommunen planlægger:

2. Ved at komme på arbejdsmarkedet så hurtigt så muligt:

3. Ved at forstå de danske værdier og komme ud på arbejdsmarkedet:

4. Ved at forstå danske værdier og deltage i indslusning: 
Question 3: Hvilket år blev Jacob Bundsgaard borgmester? (sat kun et kryds)

1. 2016 :

2. 2012:

3. 2011:

4. 2015:

\subsection{TEXT 2: IMMIGRATION POLITICS AT THE NATIONAL LEVEL}

\section{Immigration: Nytilkomne skaber nye udfordringer}

København: Allerede tidligt torsdag morgen forrige uge stod det klart, at den stigende indvandring, herunder også et stigende antal asylansøgere fra borgerkrigen i Syrien, også vil have konsekvenser for Danmark de kommende år.

"Tallene er fortsat meget høje, og vi har så stor en gruppe af indvandrere, som kom til Danmark $i 2016$ og helt tilbage $i$ 2015, som stadig mangler bolig”. Det udtaler Danmarks Statsminister Lars Løkke Rasmussen (Venstre). Som konsekvens har han nu nedsat et udvalg til at kigge på immigrationsudfordringens betydning for Danmark både på kort sigt, hvor boligmanglen og de mange ressourcer til sagsbehandling pt. topper agendaen, men også på lang sigt, hvor særlige integrationsindsatser skal strømlines til de forskellige typer migranter og flygtninge. "De flygtninge og indvandrere som kommer til vores land kommer fra meget forskellige baggrunde og har vidt forskellige præmisser for at blive integreret godt $i$ vores samfund og på vores arbejdspladser", fortsætter

Lars Løkke Rasmussen, som understreger, at god integration ikke kun handler om integration på arbejdsmarkedet. Nytilkomne udlændinge skal også forstå vores værdigrundlag, og de må have et oprigtigt ønske om at blive en del af det danske samfund også værdimæssigt. "Men når alt kommer til alt", konkluderer Løkke Rasmussen, "så er succesraten for integration bundet op på arbejdsmarkedet". Lars Løkke Rasmussen har siddet som Statsminister i Danmark siden 2015. Han kan ikke erindre, at der har været en tilsvarende krise på højde med denne tidligere.

Question 1: Hvilket land kommer immigranterne ifølge teksten bl.a. fra? (scet kun et kryds)

1. Tunesien:

2. Syrien:

3. Marokko:

4. Tyrkiet (efter Erdogans forfølgelser blev intensiveret):

Question 2: På kort sigt, hvad er så udfordringen af forøget immigration ifølge teksten? (scet kun et kryds)

1. Flygtninge uden arbejde skaber utryghed i lokalbefolkningen:

2. Boligmanglen og den forøgede omkostning til sagsbehandling:

3. Immigranter koster hvert år staten ca. 40 mio., som må tages fra andre velfærdsydelser:

4. Utryghed i visse boligområder ved store ghettodannelser i byerne: 
Question 3: Hvad mangler immigranterne sarligt ifølge teksten? (sæt kun et kryds)

1. Tøj og basale hverdagsfornødenheder:

2. Bolig:

3. Bolig og varmt tøj:

4. Et tilhørsforhold til det lokale liv f.eks. i en idrætsforening:

\subsection{TEXT 3: IMMIGRATION POLITICS AT THE EU LEVEL}

\section{OVERSKRIFT: Immigration: Nytilkomne skaber nye udfordringer}

Bruxelles: Allerede tidligt torsdag morgen forrige uge stod det klart, at den stigende indvandring, herunder også et stigende antal asylans øgere fra borgerkrigen i Syrien, også vil have konsekvenser for EU de kommende år.

"Tallene er fortsat meget høje, og vi har så stor en gruppe af indvandrere, som kom til Europa $i 2016$ og helt tilbage i 2015, som stadig mangler bolig".

Det udtaler Formanden for Europa-Kommissionen, Jean-Claude Juncker. Som konsekvens har han nu nedsat et udvalg til at kigge på immigrationsudfordringens betydning for Europa både på kort sigt, hvor boligmanglen og de mange ressourcer til sagsbehandling pt. topper agendaen, men også på lang sigt, hvor særlige integrationsindsatser skal strømlines til de forskellige typer migranter og flygtninge. "De flygtninge og indvandrere som kommer til vores region kommer fra meget forskellige baggrunde og har vidt forskellige præmisser for at blive integreret godt $i$ vores samfund og på vores arbejdspladser", fortsætter

Jean-Claude Juncker, som understreger, at god integration ikke kun handler om integration på arbejdsmarkedet. Nytilkomne udlændinge skal også forstå vores værdigrundlag, og de må have et oprigtigt ønske om at blive en del af det europæiske samfund også værdimæssigt. "Men når alt kommer til alt", konkluderer

Juncker, "så er succesraten for integration bundet op på arbejdsmarkedet".

Juncker har siddet som Formand for Europa-Kommissionen siden 2014. Han kan ikke erindre, at der har været en tilsvarende krise på højde med denne tidligere.

Question 1: Hvilket år navnte artiklen, at immigrationskrisen startede? (sct kun et kryds)

1. 2013:

2. 2014:

3. 2015:

4. 2016:

Question 2: Hvilket år blev Jean-Claude Juncker formand for Europa-Kommissionen? (sct kun et kryds)

1. 2011:

2. 2015:

3. 2014:

4. 2013: 
Question 3: Hvilke to vigtige ingredienser, som Juncker fremhæver som nødvendige for integration: (sat kun et kryds)

1. Integration på arbejdsmarkedet og kendskab til europæiske værdier:

2. En forøget byrdefordeling imellem de europæiske lande og integration på arbejdsmarkedet:

3. En forøget byrdefordeling for flygtninge og samarbejde med lejre i nærområder:

4. Et kendskab til europæiske værdier og kvinders rettigheder i Vesten:

\subsection{TEXT 4: CLIMATE POLITICS AT THE LOCAL LEVEL}

\section{Klimapolitik: Nye tiltag mod klimaforandringer}

Århus: Klimaforandringer er en realitet og har mange konsekvenser både globalt set - men også lokalt. Det drejer sig derfor om at finde både globale og lokale løsninger. Spørgsmålet optager derfor kommunen de kommende år.

"Vi har brug for at kigge på mange forskellige måder at adressere udfordringen på også $i$ kommunen. Vi kan eksempelvis regne med at vandstanden stiger".

Det udtaler Århus Borgmester Jacob Bundsgaard (Socialdemokratiet) . Som konsekvens har han nu nedsat et udvalg til at kigge på klimaudfordringens betydning for Århus Kommune både på kort sigt, hvor eksempelvis vandstigning i havnen, hyppigere skybrud og uforudsigeligt vejr kan have betydning både for folks bolig, herunder sikring af kældre, men også for erhvervslivet som er i havnen. "De udfordringer klimaforandringerne giver vores kommune er meget forskelligartet, og har derfor betydning både for vores boligsituation og vores hverdag, men også for erhvervslivet", fortsætter Jacob Bundsgaard, som påpeger, at ingen endnu kender det fulde omfang af klimaforandringerne. Derfor skal udvalget som adresserer klimaforandringerne også være permanent og inkludere alle politiske partier, da hele det danske samfund er berørt. "Eksperter kommer ofte med nye skøn", konkluderer Bundsgaard, "så det bedste vi kan gøre er at nedsctte et permanent udvalg". Jacob Bundsgaard har siddet som Borgmester i Århus siden 2011. Han blev valgt for et program om styrkelse af innovative viden. Det gælder også klimaudfordringen.

Quetion 1: Hvem rammer ifølge teksten klimaforandringerne i kommunen? (sæet kun et kryds)

1. Idrætsforeningerne (hvor banerne bliver oversvømmede) og landmænd:

2. Erhvervslivet og boligejere:

3. Boligejere og landmændene:

4. Landmænd og generelt erhvervslivet:

SPØRGSMÅL 2: Hvad var centralt i Jacob Bundsgaards valgprogram? (scet kun et kryds)

1. Særligt styrkelse af innovativ viden i erhvervslivet:

2. Særligt styrkelse af innovativ viden på universiteter:

3. Undgå unødig pesticideforbrug i landbruget: 
4. Styrkelse af innovativ viden på klimaområdet:

SPØRGSMÅL 3:Hvilken udfordring er der for boligejere?

(sat kun et kryds)

1. Deres kældre bliver oversvømmet:

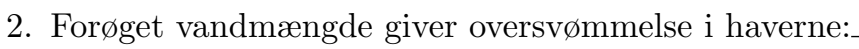

3. Folk tør ikke længere købe bolig i lavtliggende områder i byen:

4. Deres bolig falder i værdi:

\subsection{TEKST 5: CLIMATE POLITICS AT THE NATIONAL LEVEL}

\section{Klimapolitik: Nye tiltag mod klimaforandringer}

København: Klimaforandringer er en realitet og har mange konsekvenser både globalt set - men også lokalt. Det drejer sig derfor om at finde både globale og lokale løsninger. Spørgsmålet optager derfor Danmark de kommende år.

"Vi har brug for at kigge på mange forskellige måder at adressere udfordringen på også nationalt. Vi kan eksempelvis regne med, at vandstanden stiger".

Det udtaler Danmarks Statsminister Lars Løkke Rasmussen (Venstre). Som konsekvens har han nu nedsat et udvalg til at kigge på klimaudfordringens betydning for Danmark både på kort sigt, hvor eksempelvis vandstigning i havnen, hyppigere skybrud og uforudsigeligt vejr kan have betydning både for folks bolig, herunder sikring af kældre, men også for erhvervslivet som er i havnen. "De udfordringer klimaforandringerne giver vores land er meget forskelligartet, og har derfor betydning både for vores boligsituation og vores hverdag, men ogsà for erhvervslivet", fortsætter Lars Løkke Rasmussen, som påpeger, at ingen endnu kender det fulde omfang af klimaforandringerne. Derfor skal udvalget som adresserer klimaforandringerne også være permanent og inkludere alle politiske partier, da hele det danske samfund er berørt. "Eksperter kommer ofte med nye skøn", konkluderer Løkke Rasmussen, "så det bedste vi kan gøre er at nedsctte et permanent udvalg". Lars Løkke Rasmussen har siddet som Statsminister i Danmark siden 2015. Han blev valgt for et program om styrkelse af innovative viden. Det gælder også klimaudfordringen.

Question 1:Hvilke partier skal ifølge Lars Løkke Rasmussen være med til at adressere klimaudfordringen? (sæt kun et kryds)

1. Kun borgerlige partier med støtte fra Dansk Folkeparti:

2. Alle partier skal inkluderes:

3. Kun partier som finder klimaspørgsmålet centralt:

4. Partier som pt. sidder i regering:

Question 2: Hvad har Lars Løkke Rasmussen valgt at gøre i forbindelse med klimaudfordringen? (Sket kun et kryds)

1. Nedsætte en permanent kommission:

2. Forsøge at få klimaspørgsmålet til at være centralt på EU's formandskabsagenda: 
3. Trække på erhvervslivets innovative viden på området:

4. Sætte spørgsmålet på agendaen i alle Folketingets udvalg:

Question 3: Hvorfor er havnene udfordret grundet klimaforandringer? (sat kun et kryds)

1. Det bliver svære at planlægge skibsfarten grundet uforudsigeligt vejr og flere skybrud:

2. Havnene bliver oversvømmet grundet stigende havvand:

3. Der er færre som benytter havnene til erhvervsøjemed grundet dets lave beliggenhed:

4. Oversvømmelser besværliggør lystfiskeri:

\subsection{TEKST 6: CLIMATE POLITICS AT THE EU LEVEL}

\section{OVERSKRIFT: Klimapolitik: Nye tiltag mod klimaforandringer}

Bruxelles: Klimaforandringer er en realitet og har mange konsekvenser både globalt set - men også lokalt. Det drejer sig derfor om at finde både globale og lokale løsninger. Spørgsmålet optager derfor EU de kommende år.

"Vi har brug for at kigge på mange forskellige måder at adressere udfordringen på også $i$ Europa. Vi kan eksempelvis regne med at vandstanden stiger”.

Det udtaler Formanden for Europa-Kommissionen, Jean-Claude Juncker. Som konsekvens har han nu nedsat et udvalg til at kigge på klimaudfordringens betydning for Europa både på kort sigt, hvor eksempelvis vandstigning i havnen, hyppigere skybrud og uforudsigeligt vejr kan have betydning både for folks bolig, herunder sikring af kældre, men også for erhvervslivet som er i havnen. "De udfordringer klimaforandringerne giver vores region er meget forskelligartet, og har derfor betydning både for vores boligsituation og vores hverdag, men også for erhvervslivet", fortsætter

Jean-Claude Juncker, som påpeger, at ingen endnu kender det fulde omfang af klimaforandringerne. Derfor skal udvalget som adresserer klimaforandringerne også være permanent og inkludere alle politiske partier, da hele det europæiske samfund er berørt. "Eksperter kommer ofte med nye skøn", konkluderer Juncker, "så det bedste vi kan gøre er at nedsctte et permanent udvalg".

Jean-Claude Juncker har været Formand for Europa-Kommissionen siden 2014. Han blev valgt for et program om styrkelse af innovativ viden. Det gælder også klimaet.

Question 1: Hvilken titel har Jean-Claude Juncker? (Scet kun et kryds)

1. Formand for Europa-Parlamentet:

2. Formand for Europa-Kommissionens særlige udvalg for klimaspørgsmål:

3. Formand for Europa-Kommissionen:

4. Klimakommissær i Europa-Kommissionen:

Question 2: Hvem kender bedst konsekvenserne for klimaforandringerne, ifølge Jean-Claude Juncker? (Sat kun et kryds)

1. Ingen kender det fulde omfang af klimaforandringerne:

2. De klimaeksperter som sidder i Europa-kommissionens nye udvalg: 
3. Innovative videnskabsfolk, som Juncker $\emptyset$ nsker at give flere midler:

4. De rådgivere som sidder permanent i Europa-Kommissionen:

Question 3: Hvor lange har Jean-Claude Juncker haft sit nuvarende job? (Sat kun et kryds)

1. 2012:

2. 2013:

3. 2014:

4. 2015:

Table A.3: Distribution of correctly answered questions after each treatment. The data in this table are visualized in Figure 2 in the manuscript.

\begin{tabular}{|c|c|c|c|c|c|}
\hline \multicolumn{2}{|c|}{ Treatment } & \multirow[b]{2}{*}{ Question } & \multicolumn{3}{|c|}{ Answers } \\
\hline Institution & Topic & & Correct & Wrong & Total \\
\hline \multirow[t]{3}{*}{ Local } & Immigration & Q1 & 61 & 2 & 63 \\
\hline & & Q2 & 54 & 9 & 63 \\
\hline & & Q3 & 45 & 18 & 63 \\
\hline \multirow[t]{3}{*}{ Local } & Climate & Q1 & 5 & 58 & 63 \\
\hline & & Q2 & 49 & 14 & 63 \\
\hline & & Q3 & 9 & 54 & 63 \\
\hline \multirow[t]{3}{*}{ National } & Immigration & Q1 & 62 & 1 & 63 \\
\hline & & Q2 & 2 & 61 & 63 \\
\hline & & Q3 & 56 & 7 & 63 \\
\hline \multirow[t]{3}{*}{ National } & Climate & Q1 & 62 & 1 & 63 \\
\hline & & Q2 & 55 & 8 & 63 \\
\hline & & Q3 & 51 & 12 & 63 \\
\hline \multirow[t]{3}{*}{$\mathrm{EU}$} & Immigration & Q1 & 45 & 18 & 63 \\
\hline & & Q2 & 44 & 19 & 63 \\
\hline & & Q3 & 0 & 63 & 63 \\
\hline \multirow[t]{3}{*}{$\mathrm{EU}$} & Climate & Q1 & 31 & 32 & 63 \\
\hline & & Q2 & 51 & 12 & 63 \\
\hline & & Q3 & 51 & 12 & 63 \\
\hline
\end{tabular}


Table A.4: Detailed description of the eye tracking experiment.

\begin{tabular}{|c|c|c|}
\hline What & Task & Time \\
\hline Entrance of subjects & $\begin{array}{l}\text { Welcome and read loud consent form sign consent } \\
\text { form - subjects are seated at computer. }\end{array}$ & 10 min. \\
\hline Instructions & $\begin{array}{l}\text { Instruction about the experiment, its aim and how } \\
\text { to proceed - questions from subjects. }\end{array}$ & 3 min. \\
\hline Calibration & $\begin{array}{l}\text { Calibration of eye tracking equipment to subjects. } \\
\text { Participants asked to fixate a visual marker adjust } \\
\text { and fixate. }\end{array}$ & $2 \min$ \\
\hline Treatment & $\begin{array}{l}\text { Treatment exposure. Each subject is exposed to } \\
\text { six randomized texts. }\end{array}$ & 10 min. \\
\hline Comprehension check & $\begin{array}{l}\text { After each text, subjects are asked to identify a } \\
\text { few elements from the text on an onscreen ques- } \\
\text { tionnaire to ensure they have read and understood } \\
\text { the text. }\end{array}$ & 3 min. \\
\hline $\begin{array}{l}\text { Post-experimental exit } \\
\text { questionnaire }\end{array}$ & $\begin{array}{l}\text { Measuring core political variables like political } \\
\text { interest as well as a set of socio-economic demo- } \\
\text { graphic variables. }\end{array}$ & 25 min. \\
\hline $\begin{array}{l}\text { Payment, conclusion of } \\
\text { experiment and debrief- } \\
\text { ing }\end{array}$ & $\begin{array}{l}\text { Subjects are paid according to the fixed show up } \\
\text { fee and the individual gain in the public goods } \\
\text { game. Individuals participating in the eye tracking } \\
\text { part of the experiment are paid more than others. }\end{array}$ & 10 min. \\
\hline Total time & & $\approx 60 \mathrm{~min}$ \\
\hline
\end{tabular}

\section{$3 \quad$ Eye tracking equipment}

We follow the suggested reporting items by Fiedler et al. (2019) to enhance the transparency and reproducibility of eye tracking studies.

Table A.5: Detailed description of eye tracking equipment

\begin{tabular}{ll}
\hline Tracker model & Eye Link 1000 \\
Tracker producer & SR Research \\
Tracker type & Desk mounted \\
Screen resolution & $1400 \times 768$ \\
Screen size & 22 in $(16: 9)$ \\
Presentation software & SR Research Experiment Builder \\
Analysis software & R with itrackR* package \\
\hline Note: ${ }^{*}$ J. Hubbard (2015). itrackR - eyetracking analysis. \\
\multicolumn{2}{c}{ R package version 0.9.}
\end{tabular}

